\section{Boiling water injection as a non-surgical alternative treatment in hemangiomas}

\author{
Denta A.Prasetya, ${ }^{1}$ Maria Goreti, ${ }^{1}$ Cahya Y. Hasan $^{2 *}$
}

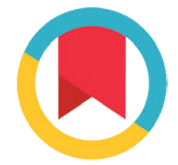

CrossMark

\title{
Abstract
}

Objective: This paper introduce boiling water as an alternative simple treatment for hemangiomas without surgery.

Methods: The patient was a 22-year-old woman with a diagnosis of high flow hemangioma based on doppler ultrasound examination. A treatment with boiling water injection was carried out in 2 stages combined with dexamethasone $0.5 \mathrm{mg}$ for 10 days and 5 days after the first and second injection respectively.
Results: Evaluation done 3 months after injection showed no hemangioma lesions.

Conclusion: The combination of boiling water injection and corticosteroid administration in the treatment of hemangiomas ended up in satisfactory results.

Keywords: Corticosteroids, Hemangioma, Injection

Cite this Article: Prasetya DA, Goreti M, Hasan CY. 2021. Boiling water injection as a non-surgical alternative treatment in hemangiomas. Journal of Dentomaxillofacial Science 6(2): 128-131. D01: 10.15562/jdmfs.v6i2.931

${ }^{1}$ Department of Oral and Maxillofacial Surgery, Faculty of Dentistry, Universitas Gadjah Mada, Yogyakarta, Indonesia

${ }^{2}$ Department of Oral and Maxillofacial Surgery, dr. Sardjito General Hospital, Yogyakarta, Indonesia
"Correspondence to: Cahya Y. Hasan, Department of Oral and Maxillofacial Surgery, RSUP dr. Sardjito Yogyakarta, Indonesia yustisiahasan@ugm.ac.id

\section{Introduction}

Hemangioma refers to various abnormalities of vascular development, including diseases caused by vascular anomalies. ${ }^{1}$ Hemangiomas are often present in the head and neck area. ${ }^{2}$ Hemangiomas that occur in the oral cavity are often found in the lips, tongue and buccal mucosa. The diagnosis of hemangioma is based on clinical symptoms supported by other examinations. The use of imaging techniques helps distinguish blood vessel abnormalities from several aggressive neoplasmic processes. Doppler ultra-sonography (USG) is an effective tool, because it is not invasive, capable of showing images of high blood flow which mark hemangiomas. As a result, it can distinguish hemangiomas from solid tumors and determine the location of feeding vessels. ${ }^{1}$

Hemangiomas can be treated by surgery, corticosteroid therapy, sclerotherapy, or radiation. ${ }^{3}$ Surgery is generally not the first choice in the treatment of hemangiomas. ${ }^{4}$ Sclerotherapy is performed by injecting the sclerosant materials into the lesion. Among the sclerosant materials include sodium morrhuate, boiling water, nitrogen mustard, sodium tetradecyl sulfate, which are common for use in the treatment of symptomatic hemangiomas and embolization of high-flow vascular malformations. ${ }^{5}$ This paper was aimed at providing an alternative simple treatment for hemangiomas without surgery.

\section{Case Report}

Revised: 24 August 2019

Accepted: 23 March 2021

Available Online: 1 August 2021
A 22-year-old woman came to the oral surgery Department of General Hospital dr. Sardjito
Yogyakarta with complaints of red, purplish, asymmetrical lower right lip. Figure 1 the patient was aware of the color change 5 months before her visit to the hospital, however, it was painless and not easily bleeding. Clinical examination found lesions in the right labial inferior, $2.5 \times 1 \mathrm{~cm}$-sized purplish red, irregular, non-stemmed and painless. Diascopy examination showed vascular lesions, then doppler ultrasound examination followed and found images of heterogenous lesions (isohypoechoic) in the lateral right of lower lip, amorphous shaped, firm boundary, $2.49 \times 1.23 \mathrm{~cm}$-sized regular edge, positive intra-lesional vascularization figure 2. The images convinced the presence of high flow hemangiomas.

In this case, the management of hemangiomas was done by two staged intra-lesional injection of boiling water combined with corticosteroid medications, dexa-methasone $0.5 \mathrm{mg}$ for 10 days and 5 days after the first and second injection respectively. Physiological examination of blood hemostasis was carried out before the treatment, resulting in a normal value. The first stage of intralesional boiling water injection was $2.5 \mathrm{ml}$ and the second stage ( 3 weeks after the first injection) was $5 \mathrm{ml}$ of boiling water injection (two different injection points, each of which was $2.5 \mathrm{ml}$ ). Both injections were performed under local anesthesia figure $3 \mathrm{~A}$ - figure $3 \mathrm{C}$.

After being heated to $100^{\circ} \mathrm{C}$, sterilized water was put into in a 3-cc syringe. Aspiration was done prior to injection to ensure that the needle has reached the depth of the vascular lesion. Positive aspiration was marked by the blood flowing into the injection 


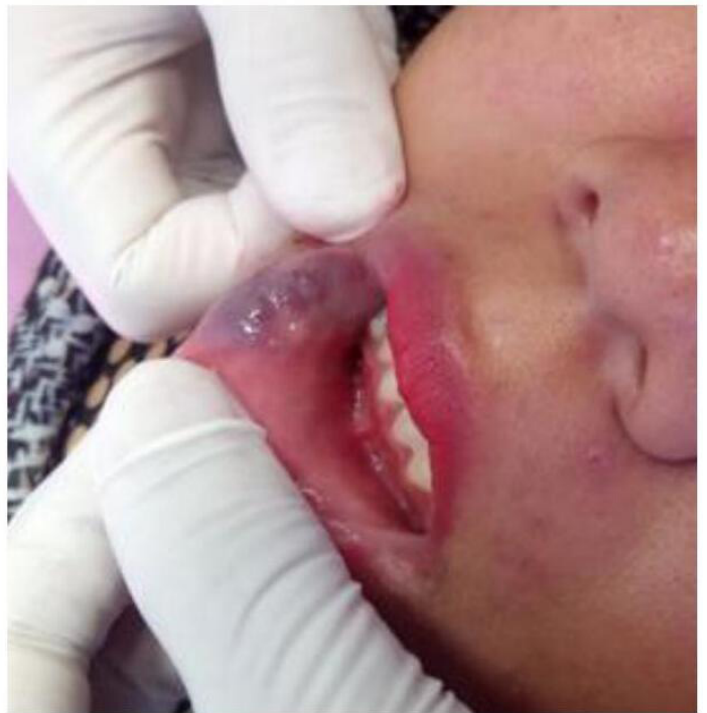

Figure 1 Clinical appearance of hemangioma lesions on the lower right lip

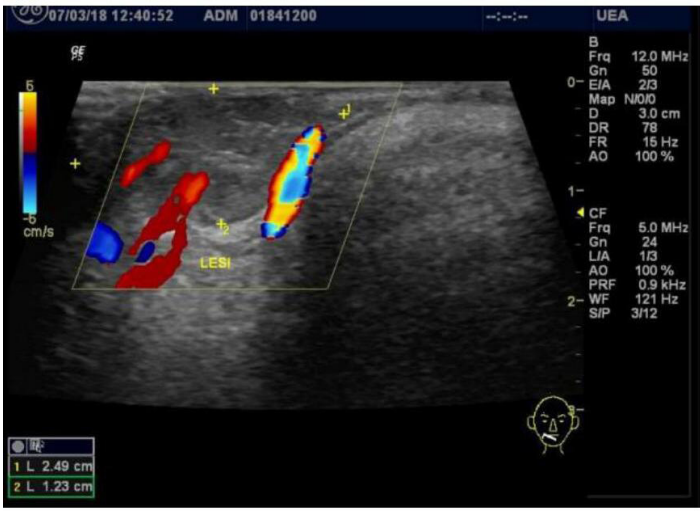

Figure 2 Results of doppler ultrasound examination: heterogenous (isohypoechoic) lesions in the lateral right lower lip, amorphous shaped, firm boundary, $2.49 \times 1.23 \mathrm{~cm}$-sized regular edge, positive intra-lesional vascularization

syringe. The injection was done slowly and immediately after the application, using gauze press the injection site until the bleeding stopped.

Evaluations were carried out on a weekly basis, resulting in decreasing surface area of the hemangioma lesions. Two months after the second stage of boiling water injection, no hemangioma lesions were found in the lower lip areafigure $4 \mathrm{~A}$ - figure $4 \mathrm{C}$.

\section{Discussion}

Hemangiomas in soft tissue is non-malignant lesions. Vascular tumors such as hemangiomas are anomalies that often occur in the head and neck to about $1-4 \%$ of the population. ${ }^{2,4,6}$ Hemangiomas
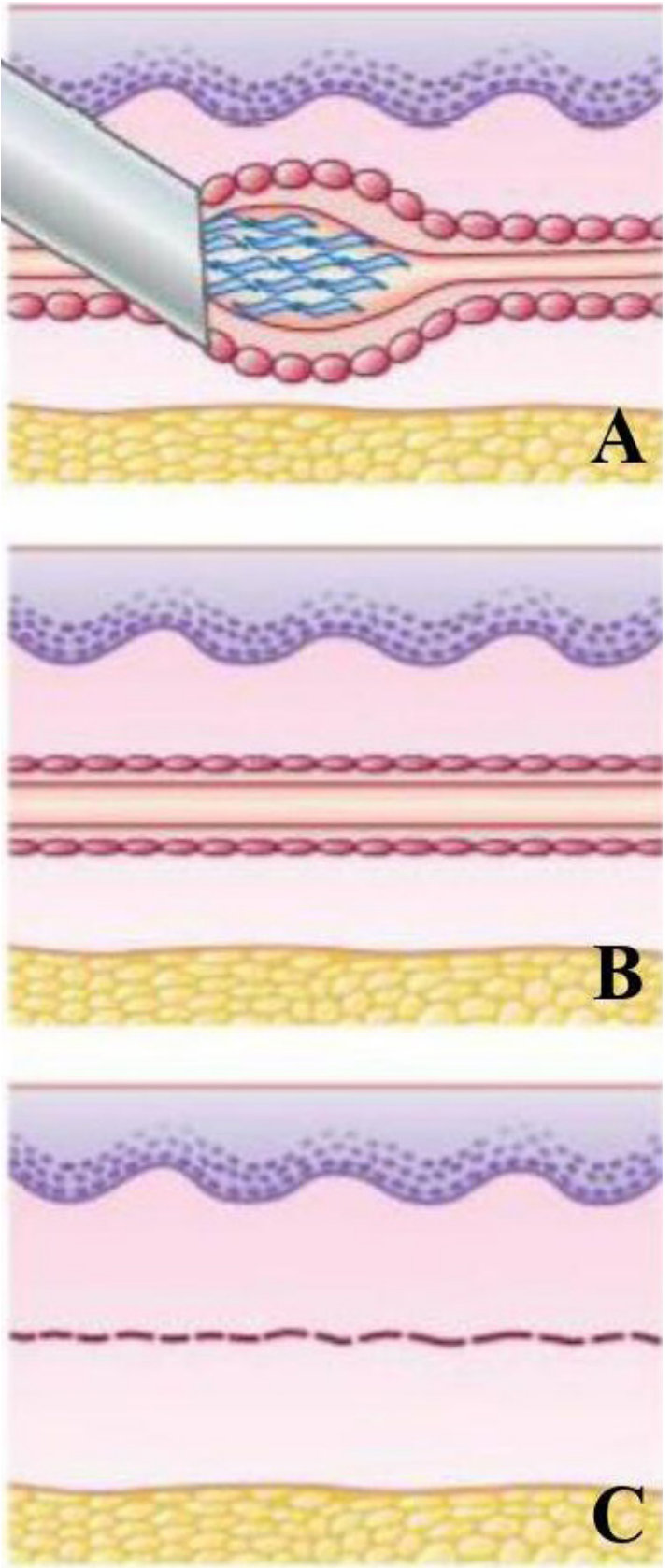

Figure 3 Stages of boiling water injection; A. Proper intravascular boiling water injection, B. Early stages of endothelial destruction and the formation of thrombosis, C. The final stage results in fibrosis tissue

can cause pain, bleeding, limited movement, stress on certain parts, abnormal blood clots and aesthetic problems. ${ }^{6}$ Hemangiomas are allegedly composed of irregular masses of endothelium-lined blood vessels filled with blood and connected to the main blood fertilization system. Angiogenesis plays a pivotal role in the formation of excessive blood vessels. The proliferation phase of hemangiomas 

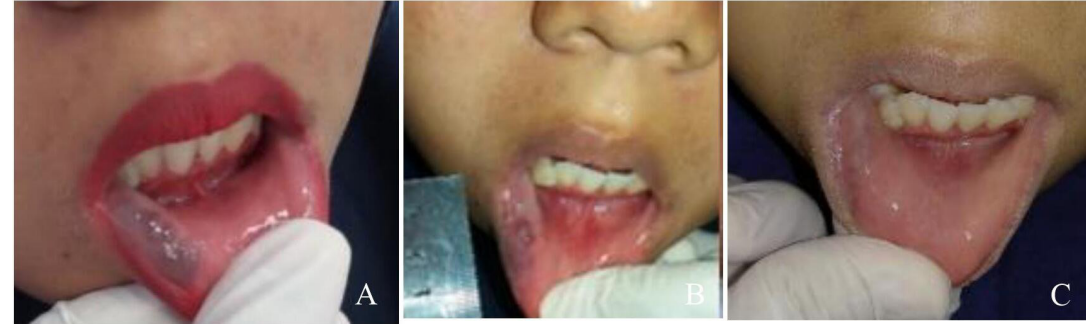

Figure 4 A. 0 day after injection, B. 14th day following injection, C. 50th day

has a high concentration of collagen type IV and Vascular Endothelial Growth Factor (VEGF).

Microscopically, hemangiomas are characterized by endothelial cell proliferation and form masses composed of different blood vessels and endothelial cells. The development of hemangiomas in the proliferation and involution phases is influenced by angiogenic factors such as VEGF. Serving as an angiogenic peptide, VEGF has the potential to control the development of hematopoietic stem cells and alteration of extracellular matrix. ${ }^{1}$

Surgery in the management of hemangiomas commonly is not the first choice. ${ }^{4}$ Therapy of this case uses a thermal agent with a principle similar to that of a sclerotic agent by irritating the endothelial surface which eventually results in a space between the endothelial surfaces. The heat from the boiling water initiates an inflammatory reaction that triggers fibrosis and removes the vascular pathway. ${ }^{6}$

The effects of boiling water injection will result in: intravascular thermal coagulation; eliminated and destroyed endothelial; and perivascular inflammation leading to fibrosis. ${ }^{8,9}$ Cell injury in boiling water-assisted treatment occurs due to physical factors trauma from high temperatures resulting in local cell death (necrosis) and limited to only particular cells. ${ }^{10}$ The treatment uses $100^{\circ} \mathrm{C}$ boiling water. Local changes occur in tissues when the amount of heat absorbed exceeds the body's system compensation mechanism. Protein degradation begins to occur at $40^{\circ} \mathrm{C}$ and are permanently denatured at $45^{\circ} \mathrm{C}$. Along with the increasing temperature and manifested by cell necrosis, the process of permanent protein denaturation occurs faster. ${ }^{11}$

Boiling water injection in this case was done in two stages. The first stage resulted in increasingly smaller, but not completely disappearing lesions. After 21-day evaluations, the second stage of injection followed, during which boiling water was injected more with two different injection points for completely eliminated lesions. The first point of injection was at the mesial end of the lesion with the injection needle pointing to the center of the lesion. Meanwhile, the second point of injection was at the distal end of the lesion with the injection needle leading to the center of the lesion. Each point received $2.5 \mathrm{ml}$ of boiling water.

Corticosteroids-assisted mechanism was expected to help reduce hemangioma lesions by inhibiting the estradiol-17 beta receptor which contributes considerably in the proliferation of hemangiomas. ${ }^{12}$ The vasoconstriction effects of corticosteroids trigger shrinkage of blood vessel capillaries, leading to smaller hemangiomas. The treatment finally resulted in the changes of the lesions into crusts on $30^{\text {th }}$ day, and complete removal without scars on $50^{\text {th }}$ day. The results favored the patient because no injury has affected the patient's appearance.

\section{Conclusion}

Combination boiling water injection and corticosteroid medication in the treatment of hemangiomas have satisfactory results after evaluation of the 50th day.

\section{Acknowledgment}

Gratitude and appreciation are extended to all faculty members of the Department of Oral and Maxillofacial Surgery, Faculty of Dentistry, Universitas Gadjah Mada, Indonesia for good cooperation in the medication therapy management for this case study.

\section{Conflict of Interest}

The authors report no conflict of interest.

\section{References}

1. Richter GT, Friedman AB. Hemangiomas and vascular malformations: current theory and management. Int J Pediatr 2012;2012: 1-10.

2. Pinto A, Haberland CM, Baker S. Pediatric soft tissue oral lesions. Dent Clin North America 2014;58: 437-453.

3. Kobayashi K, Nakao K, Kashishita S, et al. Vascular malformations of the head and neck. Auris Nasus Larynx 2012;40: 89-92.

4. Zheng JW, Zhou Q, Yang XJ, et al. Treatment guideline for hemangiomas and vascular malformations of the head and neck. Head Neck 2009;32: 1088-1098.

5. Srivathsa SH. Sclerotherapy for hemangioma of the labial mucosa. Indian J Paediatr Dermatol 2016;17: 53-55.

6. Trivedi K, Soni A, Meshack R, et al. Intraoral hemangioma: an overview of the clinical entity. J Int Clin Dent Res Organ 2015;7: 79-81.

7. Parvathidevi MK, Koppal S, Rukmangada T, et al. Management of haemangioma with sclerosing agent: a case report. BMJ Case Rep 2013;2013: 1-4.

8. Goldman MP, Guex J, Bolton J. Mechanism of action of sclerotherapy. In Goldman MP ed. Sclerotherapy treatment of varicose and telangiectatic leg veins. 6th ed. St.Louis: Elsevier; 2011. p. 173-199. 
9. Fathallah ZF. Injection of boiling hypertonic saline in the treatment of cutaneous haemangioma. Bas J Surg 2016;22: 31-37.

10. Rowan MP, Cancio LC, Elster EA, Burmeister DM, Rose LF, Natesan S, Chan RK, Christy RJ, Chung KK. Burn wound healing and treatment: review and advancements. Critical Care 2015, 19: 1-12.

11. Dewhirst M, Viglianti BL, Lora-Michiels M, Hoopes PJ Hanson MA, Thermal dose requirement for tissue effect: experimental and clinical findings. Thermal Treatment of Tissue: Energy Delivery and Assessment II. Proc SPIE 2003;4954: 37-57.
12. Rieuwpassa IE, Achmad H. Mouth preparation pasien hemangioma bibir pada anak sebelum tindakan radioterapi. J Dentomaxillofac Sci 2010;9: 86-91.

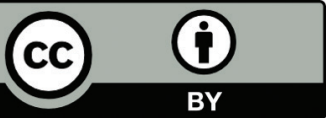

This work is licensed under a Creative Commons Attribution 